\title{
IMPROVING LEARNING OUTCOMES USING MAKE A MATCH METHOD IN FIFTH GRADE STUDENTS AT SDN O20 NORTH SAMARINDA
}

\author{
Nur Agus Salim ${ }^{1}$, Siska Oktaviani ${ }^{2}$, Tria Yuliani ${ }^{3}$ \\ ${ }^{123}$ Universitas Widya Gama Mahakam Samarinda \\ Samarinda, Kalimantan Timur Indonesia \\ nuragussalim@uwgm.ac.id, siskaavianii@gmail.com, triayuliani25@gmail.com
}

\begin{abstract}
This study intended to improve learning outcomes of events in life themes using make a match method for fifth grade students at SDN 020 Samarinda Utara in 2018/2019 academic year. The type of research used is CAR that is carried out in II cycles and each cycle consists of 3 meetings. The results showed that (1) The application of the make a match method in learning can increase the activities of teachers and students. The results reveal from the observations of teacher activity in the first cycle scored 58.8 to 78.8 in the second cycle. It was also proved by the results which getting a value of 60 in cycle I, increasing in cycle II with a value of 86.6. (2) The learning outcomes on theme 7 of the social studies subject matter have increased after taking action. It can be seen from the average class in the first cycle of 71.33 with a percentage of completeness that is $33.3 \%$, in the second cycle to 80.83 with a percentage of completeness of $83.3 \%$. (3) students' skills in making mind maps increased in cycle I gained an average value of 68.8, $p$ and in cycle II scored 80.2.
\end{abstract}

Keywords: Learning Outcomes, Make a Match

\section{Introduction}

Pendidikan merupakan proses membantu dalam pengembangan diri manusia. Pendidikan merupakan proses penanaman nilai-nilai kehidupan dalam diri seseorang yang akan membentuk karakter orang tersebut. Pendidikan juga dapat diartikan sebagai pembelajaran pengetahuan, keterampilan, dan kebiasaan, yang akan diimplementasikan dalam kehidupan nyata. Pendidikan sendiri terjadi sepanjang hayat, sejak seseorang lahir hingga akhir hayatnya.

Berdasarkan UU RI No. 20 tahun 2003 pasal 13 jalur pendidikan terdiri atas: Pendidikan formal adalah pendidikan yang diselenggarakan secara berstruktur dan berjenjang, pendidikan formal dilaksanakan di sekolah dan perguruan tinggi. Pendidikan nonformal merupakan pendidikan yang diselenggarakan secara bertahap dan berstruktur, seperti pendidkan anak usia dini, lembaga kursus dan lain-lain. Pendidikan informal yaitu pendidikan yang didapat di lingkungan keluarga dan masyarakat dan terjadi secara alamiah.

Sistem pendidikan nasional di Indonesia telah diatur oleh Undang-Undang (UU) Republik Indonesia No. 20 tahun 2003. Pasal 6 ayat (1) menyatakan bahwa setiap warga negara yang berusia tujuh sampai lima belas tahun wajib mengikuti pendidikan dasar, yakni 6 tahun di sekolah dasar dan 3 tahun di pendidikan sekolah menengah pertama. Hal tersebut menunjukan bahwa pendidikan dasar merupakan masa-masa yang sangat penting dalam pendidikan formal karena merupakan dasar dari segala pendidikan yang berbasis kompetensi.

Pendidikan di sekolah dasar yang ditempuh selama 6 tahun mulai dari kelas 1 sampai kelas 6 , merupakan masa-masa pembentukan karakter siswa dan mengetahui potensi diri siswa, serta merencanakan masa depan, selain itu tujuan dari proses pendidikan di sekolah dasar adalah membekali siswa kemampuan dasar membaca, menulis, berhitung serta pengetahuan dan keterampilan yang merupakan pondasi untuk jenjang pendidikan berikutnya. Maka peran guru di sekolah dasar sangatlah penting, karena untuk membangun rumah yang kokoh tentu kita harus membuat pondasi yang kuat, sama halnya dengan pendidikan di sekolah dasar yang harus senantiasa memberikan pengalaman belajar yang memadai untuk pengalaman belajar di jenjang pendidikan berikutnya.

Menurut Susanto (2016) belajar merupakan kegiatan yang dilakukan seseorang dengan sengaja dan dalam keadaan sadar dengan tujuan mendapatkan pemahaman dan pengetahuan baru, yang memungkinkan terjadinya perubahan 
perilaku ke arah yang lebih baik dalam berpikir, merasa, dan bertindak. Secara umum definisi belajar adalah suatu usaha yang dilakukan seseorang untuk melakukan perubahan ke arah yang lebih baik sebagai hasil pengalamannya berinteraksi dengan lingkungannya. Belajar juga diartikan sebagai proses dari tidak tahu menjadi tahu.

Setiawan (2017) mengatakan bahwa kegiatan belajar dipengaruhi oleh dua faktor utama, yaitu faktor internal dan faktor eksternal. Faktor internal merupakan faktor yang berasal dari diri peserta didik, sedangkan faktor eksternal merupakan faktor yang berasal dari luar diri siswa (faktor sosial). Faktor internal meliputi faktor jasmaniah, psikologis dan faktor kelelahan, adapun yang termasuk faktor eksternal adalah faktor keluarga, sekolah dan masyarakat. Faktorfaktor tersebut sangat memengaruhi kegiatan belajar siswa yang akan berdampak pada hasil atau capaian siswa setelah melakukan kegiatan belajar.

Hasil belajar merupakan perubahan perilaku dan kemampuan siswa baik itu kemampuan kognitif (pengetahuan), afektif (sikap) dan psikomotorik (keterampilan) setelah melakukan pembelajaran. Hasil belajar juga diartikan sebagai capaian siswa setelah mengikuti proses belajar mengajar. Hasil belajar juga dijadikan tolak ukur keberhasilan guru dalam melaksanakan kegiatan belajar mengajar.

Berdasarkan wawancara yang dilakukan terhadap wali kelas V SDN 020 Samarinda Utara, guru menjelaskan pembelajaran yang dilakukan selama ini adalah pembelajaran yang berpusat pada guru, dan masih jarang menggunakan metode pembelajaran yang melibatkan siswa aktif secara keseluruhan. Dari analisis data hasil belajar siswa pada muatan pembelaaran IPS didapatkan hasil hanya $46 \%$ atau sekitar 11 siswa dari 24 siswa yang mendapat nilai di atas KKM yaitu 70 . Hasil belajar tersebut belum mencapai target yang ditentukan, yaitu $85 \%$.

Salah satu cara yang dapat dilakukan oleh guru untuk mencapai tujuan dan hasil belajar yang maksimal adalah dengan menciptakan situasi pembelajaran yang memungkinkan siswa untuk belajar dengan nyaman dan aktif dalam mengikuti proses pembelajaran. Maka guru harus memilih metode pembelajaran yang tepat dalam menyampaikan materi pembelajaran. Metode merupakan cara atau jalan yang ditempuh oleh guru untuk menyampaikan materi pembelajaran sehingga tujuan pembelajaran dapat tercapai.
Metode yang baik harus senantiasa sesuai dengan kondisi dan karakter siswa, (Darmadi, 2017).

Menurut Kusnadi (2018) metode pembelajaran adalah prosedur, langkah-langkah dan cara yang digunakan guru untuk mencapai tujuan pembelajaran. Secara umum, metode pembelajaran adalah cara atau jalan yang di tempuh guru dalam menyampaikan materi agar siswa mudah menerima materi yang disampaiakan, sehingga tujuan dan hasil belajar akan tercapai.

Salah satu metode pembelajaran yang dapat digunakan adalah metode pembelajaran make a match. Metode pembelajaran make a match merupakan salah satu jenis model pembelajaran kooperatif, dimana siswa diminta untuk mencari pasangan dari kartu yang dipegang. Dalam penerapannya metode make a match membutuhkan media kartu yang berisi pertanyaan dan jawaban, dimana siswa akan mencari pasangan dari kartu yang dipegang.

Metode make a match adalah metode pembelajaran dengan cara mencari pasangan sambil mengenal suatu konsep dalam semua mata pelajaran dan tingkatan kelas. Penerapan metode ini dapat menciptakan suasana belajar yang menyenangkan karena melibatkan berbagai aktivitas belajar baik mental maupun fisik (Mariyaningsih \& Hidayati, 2018). Penerapan metode make a match akan melatih siswa berpartisipasi aktif, melatih kerja sama siswa, dan menanamkan karakter tanggung jawab.

Penggunaan metode make a match merupakan salah satu alternatif agar terciptanya situasi pembelajaran yang aktif dan menyenangkan, karena sesuai dengan karakter siswa di sekolah dasar yang pada umumnya masih suka bermain. Hal tersebut akan berdampak pada hasil belajar siswa.

Berdasarkan latar belakang masalah yang ada, maka penelitian ini diajukan dengan judul "Peningkatan Hasil Belajar Menggunakan Metode Make a Match Siswa Kelas V di SD Negeri 020 Samarinda Utara".

\section{Method}

Jenis penelitian ini adalah penelitian tindakan kelas (PTK). Istilah dalam bahasa Inggris adalah Classroom Action Research (CAR), yaitu sebuah penelitian yang dilakukan dikelas. Penelitian tindakan kelas adalah suatu pencermatan terhadap kegiatan belajar berupa sebuah tindakan yang sengaja dimunculkan dan 
terjadi dalam sebuah kelas secara bersama. Penelitian tindakan kelas merupakan penelitian tindakan yang dilakukan di kelas dengan tujuan memperbaiki mutu praktik pembelajaran. Menurut Arikunto, dkk., (2017), penelitian tindakan kelas merupakan penelitian yang menjelaskan apa yang terjadi apabila suatu kelas diberikan perlakuan, sekaligus memaparkan segala proses dari awal sampai akhir dan dampak dari perlakuan tersebut.

Adapun prosedur penelitiannya adalah sebagai berikut:

\section{Tahap 1: Menyusun rancangan tindakan (Planning)}

Dalam tahap penyusunan rancangan ini peneliti menentukan titik antar fokus peristiwa yang perlu mendapatkan perhatian khusus untuk diamati kemudian membuat sebuah instrumen pengamatan untuk membentu peneliti merekam fakta yang terjadi selama tindakan berlangsung. Selain itu peneliti perlu melakukan hal-hal berikut:

1) Membuat Rencana Pelaksanaan Pembelajaran (RPP) yang akan diterapkan dalam proses pembelajaran;

2) Menentukan skenario pembelajaran;

3) Menyiapkan instrumen penelitian yang terdiri dari:

- Lembar observasi kegiatan belajar siswa selama penelitian berlangsung.

- Lembar observasi kegiatan guru selama penelitian berlangsung.

- Lembar kerja peserta didik pada pertemuan 1 dan 2 berupa soal essay berjumlah 5 nomor.

- Soal evaluasi untuk melihat hasil belajar pada siklus I berupa soal essay berjumlah 10 nomor.

4) Melakukan koordinasi dengan pengamat mengenai pelaksanaan tindakan.

\section{Tahap 2: Pelaksanaan Tindakan (Action)}

Tahap ke-2 dari penelitian tindakan adalah pelaksanaan yang merupakan implementasi atau penerapan isi rancangan dan RPP yang sudah dibuat, yaitu mengenakan tindakan dikelas. Dalam proses pembelajaran guru menyampaikan materi pembelajaran secara langsung didepan kelas. Kemudian siswa dibagi menjadi 2 kelompok besar secara heterogen. Tahap selanjutnya peneliti memberi masing-masing siswa di kelompok 1 sebuah kartu yang berisi soal, dan siswa di kelompok 2 diberi kartu yang berisi jawaban. Semua siswa tidak boleh membuka kartu sebelum diberi aba-aba. Setelah diberi aba-aba siswa mebuka kartu dan langsung mencari pasangan kartu yang dipegang. Siswa yang berhasil mencocokkan kartunya dalam batas waktu tertentu diberikan poin. Hal tersebut dilakukan berulang kali sampai siswa mendapatkan beberapa kartu berbeda. Diakhir siklus akan dilakukan tes akhir siklus secara individu untuk mengukur sejauh mana pemahaman siswa terhadap apa yang telah dipelajari.

\section{Tahap 3 : Pengamatan (Observing)}

Kegiatan observasi dilaksanakan pada saat proses pembelajaran berlangsung. Observasi bertujuan untuk melihat secara langsung bagaimana partisispasi siswa pada saat proses pembelajaran dan aktivitas guru dalam menerapkan metode make a match. Data yang dikumpulkan adalah semua data tentang proses perubahan akibat implementasi tindakan dan hasil kegiatan pembelajaran setelah pelaksanaan.

\section{Tahap 4 : Refleksi (Reflecting)}

Setelah melakukan tindakan dan pengamatan peneliti melakukan refleksi untuk melakukan evaluasi hasil tindakan yang telah dilakukan. Dari refleksi kemungkinan muncul permasalahan yang perlu mendapatkan perhatian, sehingga peneliti melakukan perencanaan ulang, tindakan ulang, dan pengamatan ulang dan berkelanjutan sampai permasalahan sudah bisa teratasi dengan siklus, rencana, tindakan, observasi, dan refleksi.

Pengambilan data pada penelitian ini menggunakan dua teknik, yaitu: teknik tes dan teknik non tes. Sumber data penelitian akan diperoleh secara langsung dari respon siswa. Alat pengumpulan data yang digunakan adalah lembar observasi, tes hasil belajar dan dokumentasi.

Analisi data merupakan proses meencari dan menyusun secara sistematis data yang diperoleh dari hasil lembar observasi, catatan lapangan dan dokumentasi, dengan cara mengorganisasikan data ke dalam kategori, menjabarkan ke dalam unit-unit, melakukan sintesa, menyusun kedalam pola, memilih mana yang penting dan akan dipelajari, dan membuat kesimpulan sehingga mudah dipahami oleh diri sendiri dan orang lain. selama penelitian Data yang diperoleh dalam penelitian ini merupakan data mentah. Agar data tersebut dapat 
memberikan informasi yang dibutuhkan, maka data tersebut dianalisis menggunakan teknikteknik tertentu agar memperoleh suatu kesimpulan. Tujuannya adalah untuk memperoleh bukti kepastian apakah terjadi perbaikan, peningkatan atau perubahan dalam pembelajaran sebagaimana yang diharapkan. Dalam penelitian ini digunakan analisis data statistik deskriptif kuantitatif dan deskriptif kualitatif. Teknik analisis data statistik deskriptif digunakan untuk menganalisis data dengan cara mendeskripsikan data yang diperoleh di lapangan.

Analisis deskriptif kuantitatif yang berupa angka yaitu skor dari tes hasil belajar dan persentase peningkatan hasil belajar siswa dalam setiap siklus. Adapun rumus yang digunakan adalah sebagai berikut:

1) Tes hasil belajar siswa secara individu dihitung dengan rumus:

$$
\mathrm{S}=\frac{\sum \text { skor nila yang di proleh }}{\sum \text { skor maxsimal }} \times 100
$$

(Djamarah, 2014)

2) Untuk menghitung persentase ketuntasan siswa digunakan rumus sebagai berikut:

$$
P=\frac{\sum \text { siswa yang tuntas belajar }}{\sum \text { siswa }}
$$

(Daryanto, 2018)

3) Sedangkan untuk menghitung rata-rata kelas digunakan rumus sebagai berikut:

$$
\bar{X}=\frac{\sum X}{\sum N}
$$

(Daryanto, 2018)

Apabila nilai rata-rata siklus II lebih besar dari pada nilai rata-rata siklus I, maka dapat diambil kesimpulan bahwa prestasi belajar meningkat. Analisis data tersebut digunakan pada tahap refleksi, digunakan untuk rencana perbaikan pembelajaran pada siklus berikutnya.

Data hasil observasi aktivitas siswa selama proses pembelajaran dengan menggunakan metode make a match dianalisis secara deskriptif kualitatif. Untuk menganalisis data kualitatif digunakan rumus sebagai berikut:

$$
N p=\frac{R}{S m} \times 100
$$

Analisis data ini dilakukan pada saat refleksi. Hasil analisis ini digunakan untuk melakukan perencanaan lanjutan dalam siklus selanjutnya. Hasil analisis juga dijadikan bahan refleksi dalam memperbaiki rancangan pembelajaran atau bahkan mungkin sebagai bahan pertimbangan dalam penentuan model pembelajaran yang tepat.

\section{Result and Discussion \\ Result}

Penelitian tindakan kelas ini dilaksanakan dalam 2 siklus, dan setiap siklus terdiri dari 3 pertemuan. Diakhir setiap siklus diadakan evaluasi untuk mengetahui tingkat ketuntasan siswa. Untuk lebih jelasnya, berikut adalah deskripsi pelaksanaan penelitian.

\section{Pelaksanaan Tindakan Siklus I}

Pelaksanaan tindakan pada siklus I ini terbagi dalam 4 tahap, yaitu tahap perencanaan tindakan, tahap pelaksanaan tindakan, tahap observasi dan tahap refleksi. Adapun proses pelaksanaan siklus I akan diuraikan sebagai berikut:

\section{1) Tahap Perencanaan Tindakan}

Pada tahap perencanaan tindakan ini dilakukan persiapan dan perencanaan kegiatan pembelajaran menggunakan metode make a match. Adapun kegiatan yang dilakukan pada tahap perencanaan ini adalah sebagai berikut:

a) Menyiapkan Rencana Pelaksanaan Pembelajaran (RPP) menggunakan metode make a match. Pada pelaksanaan pembelajaran siklus I materi yang disampaikan meliputi kompetensi dasar (KD) 3.4 Mengidentifikasi faktor-faktor penting penyebab penjajahan bangsa Indonesia dan upaya bangsa Indonesia dalam mempertahankan kedaulatannya, dan KD 4.4 Menyajikan hasil identifikasi mengenai faktor-faktor penting penyebab penjajahan bangsa Indonesia dan upaya bangsa Indonesia dalam mempertahankan kedaulatannya.

b) Menyiapkan media dan sumber belajar yang digunakan dalam kegiatan pembelajaran terkait metode make a match dan materi yang akan disampaikan.

c) Menyiapkan instrumen penelitian yang terdiri dari:

- Lembar observasi kegiatan belajar siswa selama penelitian berlangsung. 
- Lembar observasi kegiatan guru selama penelitian berlangsung.

- Lembar kerja peserta didik pada pertemuan 1 dan 2 berupa soal essay berjumlah 5 nomor.

- Soal evaluasi untuk melihat hasil belajar pada siklus I berupa soal essay berjumlah 10 nomor.

d) Melakukan koordinasi dengan pengamat mengenai pelaksanaan tindakan.

\section{2) Tahap Pelaksanaan Tindakan}

Tahap pelaksanaan ini dilakukan sebanyak 3 kali pertemua, masing-masing pertemuan dilaksanakan dalam 3 X 35 Menit atau 3 jam pelajaran, yang terbagi dalam kegiatan awal, kegiatan inti, dan kegiatan penutup. Sedangkan tes akhir siklus dilaksanakan pada pertemuan ke-3 setelah menyampaikan materi.

Dalam penelitian ini, peneliti bertindak sebagai guru. Dalam penelitian ini juga melibatkan seorang rekan yang akan bertindak sebagai observer, atau pengamat kegiatan pembelajaran. Kegiatan pembelajaran yang dilakukan mengacu pada rencana pelaksanaan pembelajaran (RPP) yang sudah disiapkan. Pokok bahasan pada pembelajaran di siklus I ini adalah peristiwa kebangsaan pada masa penjajahan. Berikut deskripsi kegiatan pembelajaran selama penelitian.

Pertemuan I dilaksanakan pada hari Selasa tanggal 9 April 2019 dengan indikator mengidentifikasi latar belakang kedatangan bangsa Eropa di Indonesia. Kegiatan pembelajaran dibuka dengan mengucap salam dan mengajak semua siswa untuk berdoa menurut agama dan kepercayaan masing-masing. Kemudian guru mengecek kehadiran siswa dan mengajak siswa untuk menyanyikan lagu Indonesia Raya. Dilanjutkan dengan memberi apersepsi tentang penjajahan yang terjadi di Indonesia untuk mengetahui pengetahuan yang sudah dimiliki siswa. Kemudian dilanjutkan dengan memotivasi siswa dengan mengkaitkan penjajahan yang pernah terjadi, agar siswa lebih giat belajar.

Kegiatan inti diawali dengan siswa mengamati gambar yang ada di buku siswa, Kemudian guru melakukan tanya jawab bersama siswa, dan dilanjutkan dengan guru menjelaskan materi pelajaran. Setelah selesai guru membagi siswa menjadi 2 kelompok besar untuk melaksanakan penerapan metode make a match. Kelompok pertama akan dibagikan kartu yang berisi soal dan kelompok kedua akan dibagikan kartu yang berisi jawaban. Setiap siswa akan mencari pasangan dari kartu yang dipegang. Setelah selesai siswa membawa pasangan kartu yang dipegang kepada guru untuk dikonfirmasi pasangan setiap kartu. Kegiatan ini diulang hingga 3 kali.

Pada kegiatan akhir siswa mengerjakan lembar kerja siswa yang sudah disiapkan. Setelah selesai guru mengajak siswa untuk mengoreksi jawaban bersama-sama dilanjutkan guru mengajak siswa untuk membuat kesimpulan dari apa yang telah dipelajari. Kemudian guru menutup pelajaran dan mengucap salam.

Pertemuan II dilaksanakan pada hari Rabu tanggal 10 April 2019, dengan indikator menjelaskan sistem tanam paksa pemerintahan kolonial Belanda. Kegiatan pembelajaran dibuka dengan mengucap salam dan mengajak semua siswa untuk berdoa menurut agama dan kepercayaan masing-masing. Kemudian guru mengecek kehadiran siswa dan mengajak siswa untuk menyanyikan lagu Indonesia Raya. Dilanjutkan dengan memberi apersepsi untuk mengetahui pengetahuan yang sudah dimiliki siswa. Kemudian dilanjutkan dengan memotivasi siswa dan menyampaikan tujuan pembelajaran.

Pada kegiatan inti diawali dengan siswa membaca teks sistem tanam paksa pemerintah kolonial Belanda. Kemudian guru melakukan tanya jawab bersama siswa, dan dilanjutkan dengan guru menjelaskan materi pelajaran. Setelah selasai guru membagi siswa menjadi 2 kelompok besar untuk melaksanakan penerapan metode make a match. Kelompok pertama akan dibagikan kartu yang berisi soal dan kelompok kedua akan dibagikan kartu yang berisi jawaban. Setiap siswa akan mencari pasangan dari kartu yang dipegang. Setelah selesai siswa membawa kartu yang dipegang kepada guru untuk dikonfirmasi pasangan setiap kartu. Setiap siswa yang membawa pasangan kartu nya dengan benar akan mendapatkan poin. Kegiatan ini diulang hingga 3 kali.

Kegiatan akhir siswa mengerjakan lembar kerja siswa yang sudah disiapkan. Setelah selesai guru mengajak siswa untuk mengoreksi jawaban bersama-sama dilanjutkan dengan guru mengajak siswa untuk membuat kesimpulan dari apa yang telah dipelajari. Kemudian guru menutup pelajaran dan mengucap salam.

Pertemuan III dilkasanakan pada hari Kamis tanggal 11 April 2019 dengan indikator 
menuliskan peristiwa-peristiwa sejarah pada masa awal pergerakan nasional. Kegiatan pembelajaran dibuka dengan mengucap salam dan mengajak semua siswa untuk berdoa menurut agama dan kepercayaan masing-masing. Kemudian guru mengecek kehadiran siswa dan mengajak siswa untuk menyanyikan lagu Indonesia Raya. Dilanjutkan dengan memberi apersepsi untuk mengetahui pengetahuan yang sudah dimiliki siswa. Kemudian dilanjutkan dengan memotivasi siswa dan menyampaikan tujuan pembelajaran.

Pada kegiatan inti diawali dengan memberikan penjelasan materi faktor-faktor kegagalan perjuangan para pendahulu dalam melawan pemerintah kolonial. Setelah selesai guru melakukan tanya jawab mengenai materi yang baru saja disampaikan. Kemudian guru mengajak siswa untuk membuat kesimpulan. Setelah selesai guru membagikan soal evaluasi akhir siklus untuk mengetahui hasil belajar siswa setelah dilakukan tindakan dengan menerapkan metode make a match dalam proses pembelajaran. Setelah selesai mengerjakan soal evaluasi, siswa membuat peta pikiran peristiwa kebangsaan masa penjajahan. Pada kegiatan akhir guru mengajak siswa untuk berdoa bersama, dan mengakhiri pelajaran dengan mengucap salam.

Hasil tes evaluasi pada siklus I dapat dilihat pada tabel berikut:

Tabel 2 Rekapitulas Hasil Belajar Siklus I

\begin{tabular}{|l|c|c|}
\hline Keterangan & Jumlah Siswa & Persentase \\
\hline Tuntas & 8 & $33,3 \%$ \\
\hline Tidak Tuntas & 16 & $66,6 \%$ \\
\hline \multicolumn{2}{|c|}{ Rata-rata } & 71,33 \\
\hline
\end{tabular}

Berdasarkan tabel 4.2 dapat dijabarkan bahwa dari 24 siswa kelas $\mathrm{V}$, terdapat 8 siswa atau $33,3 \%$ sudah mencapai nilai ketuntasan dalam penelitian. Dan sebanyak 16 siswa atau $66,6 \%$ belum mencapai nilai ketuntasan dalam penelitian. Selain hasil belajar, pada siklus I ini diperoleh nilai keteramplan siswa dengan rata-rata 68,8 .

\section{3) Tahap Observasi}

Observasi dilakukan selama kegiatan penelitian tindakan kelas berlangsung menggunakan lembar observasi yang sudah disiapkan sebelumnya. Lembar observasi siswa diisi oleh peneliti sendiri, sedangkan lembar observasi guru diisi oleh observer. Observasi dilakukan disetiap pertemuan.

\section{a) Observasi Aktivitas Guru}

Berdasarkan observasi tentang aktivitas guru diperoleh hasil bahwa guru telah melaksanakan kegiatan pembelajaran pada siklus ini dengan cukup baik. Pada pertemuan pertama kegiatan pembelajaran kurang sesuai dengan rencana peaksanaan pembelajaran. Guru kurang memperhatikan siswa pada saat menjelaskan materi pelajaran, selain itu guru juga kurang komunikatif, sehingga siswa kurang bersemangat dalam belajar, pada pertemuan pertama ini guru memperoleh nilai sebesar 48,8 .

Pertemuan kedua guru memperoleh nilai sebesar 56,6. Guru mulai memperhatikan siswa dan lebih komunikatif namun guru hanya fokus pada beberapa siswa. Suara guru yang kurang keras membuat siswa yang duduk dibagain belakan tidak memperhatiakan kegiatan pembelajaran. Namun pada pertemuan kedua ini guru dapat memberi kesimpulan sesuai dengan apa yang telah dipelajari selaian itu bahasa yang digunakan guru juga mudah dipahami oleh siswa.

Observasi pada pertemuan ketiga menunjukan aktivitas guru kembali meningkat, hal ini ditandai dengan guru mampu memusatkan perhatian siswa dengan suara yang lantang dan banyaknya siswa yang antusias dalam melaksanakan intruksi guru. Selain itu guru juga dapat mengkaitkan materi pelajaran dengan kehidupan sehari-hari siswa. Guru juga memberikan kesimpulan sesuai dengan yang telah dipelajari. Namun ada pertemuan ketiga ini guru tidak menerapkan metode make a match. Pada perteman ini guru memperoleh nilai sebesar 58,8. b) Observasi Aktivitas Siswa

Observasi aktivitas siswa pada sisklus ini dilakukan disetiap pertemuan. Pada peremuan pertama menunjukan bahwa sebagian besar siswa memperhatikan pada saat guru menjelaskan materi pelajaran selain itu sebagian besar siswa juga terlihat aktif merespon stimulus yang diberikan oleh guru. Beberapa siswa masih terlihat bermain dan asik mengobrol, Selain itu pada saat metode make a match diterapkan untuk pertama kali sebagian besar siswa terlihat kurang antusias mengikuti arahan guru. Pada pertemuan ini nilai aktivitas siswa sebesar 53,3.

Observasi aktivitas siswa meningkat pada pertemuan kedua hal ini ditandai dengan meningkatnya jumlah siswa yang antusias dalam melaksanakan arahan guru. Nilai aktivitas siswa pada pertemuan ini meningkat menjadi 60. Sama seperti pertemuan kedua, pada pertemuan ketiga 
diperoleh bahwa sudah lebih dari setengah jumlah siswa terlihat memperhatikan penjelasan guru, aktif merespon stimulus yang diberikan, serta bersemangat menikuti pelajaran. Namun nilai yang diperoleh dari lembar aktivitas siswa belum meningkat dari pertemuan kedua, yaitu 60. Pada pertemuan ketiga guru tidak menerapkan metode make a match hal ini dikarenakan pada pertemuan ini dilakukan evaluasi akhir siklus.

\section{4) Tahap Refleksi}

Setelah melaksanakan kegiatan pada siklus I, peneliti melakukan refleksi terhadap kegiatan pembelajaran ada siklus I sebagai bahan pertimbangan dalam melaksanakan siklus II. Berdasarkan data hasil tes akhir siklus I peneliti dapat menyimpulkan bahwa hasil belajar siswa sudah meningkat. Namun hasil tersebut belum mencapai indikator keberhasilan dalam penelitian ini, sehingga peneliti melanjutkan penelitian ini pada tahap selanjutnya yaitu siklus II.

Berdasarkan hasil observasi kegiatan belajar siswa pada pertemuan 1 , pertemuan 2 , dan pertemuan 3 diperoleh hasil sebagai berikut:

a. Kegiatan belajar kurang sesuai dengan rencana pelaksanaan pembelajaran.

b. Sebagian siswa terlihat pasif (kurang berpartisipasi) dalam mengikuti kegiatan pembelajaran.

c. Beberapa siswa mengerjakan tugas individu dengan berdiskusi dengan teman sebangkunya.

Berdasarkan permasalahan tersebut, peneliti merencanakan pada kegiatan di siklus ke2 akan memberikan poin tambahan pada siswa yang ikut aktif dalam kegiatan pembelajaran, seperti menyampaikan pendapatnya, mengajukan pertanyaan bila ada hal yang tidak dipahami, menanggapi pertanyaan teman, dan menjawab pertanyaan yang disampaikan guru. Serta mengurangi poin bagi siswa yang melakukan diskusi pada saat mengerjakan tugas individu.

\section{Pelaksanaan Tindakan Siklus II \\ 1) Tahap Perencanaan tindakan}

Pada tahap perencanaan tindakan ini dilakukan persiapan dan perencanaan kegiatan pembelajaran menggunakan metode make a match. Adapun kegiatan yang dilakukan pada tahap perencanaan ini adalah sebagai berikut:
a) Menyiapkan
rencana
pelaksanaan

pembelajaran (RPP) menggunakan metode make a match. Pada pelaksanaan pembelajaran siklus II materi yang disampaikan meliputi kompetensi dasar (KD) 3.4 Mengidentifikasi faktor-faktor penting penyebab penjajahan bangsa Indonesia dan upaya bangsa Indonesia dalam mempertahankan kedaulatannya, dan KD 4.4 Menyajikan hasil identifikasi mengenai faktor-faktor penting penyebab penjajahan bangsa Indonesia dan upaya bangsa Indonesia dalam mempertahankan kedaulatannya.

b) Menyiapkan media dan sumber belajar yang digunakan dalam kegiatan pembelajaran terkait metode make a match dan materi yang akan disampaikan.

c) Menyiapkan instrumen penelitian yang terdiri dari:

- Lembar observasi kegiatan belajar siswa selama penelitian berlangsung.

- Lembar observasi kegiatan guru selama penelitian berlangsung.

- Lembar kerja peserta didik pada pertemuan 1 dan 2 berupa soal essay berjumlah 5 nomor.

- Soal evaluasi untuk melihat hasil belajar pada siklus II berupa soal essay berjumlah 10 nomor.

d) Melakukan koordinasi dengan pengamat mengenai pelaksanaan tindakan.

\section{2) Tahap Pelaksanaan}

Tahap pelaksanaan ini dilakukan sebanyak 3 kali pertemua, masing-masing pertemuan dilaksanakan dalam 3 X 35 Menit atau 3 jam pelajaran, yang terbagi dalam kegiatan awal, kegiatan inti, dan kegiatan penutup. Sedangkan tes akhir siklus dilaksanakan pada pertemuan ke-3 setelah menyampaikan materi.

Dalam penelitian ini, peneliti bertindak sebagai guru. Dalam penelitian ini juga melibatkan seorang rekan yang akan bertindak sebagai observer, atau pengamat kegiatan pembelajaran. Kegiatan pembelajaran yang dilakukan mengacu pada rencana pelaksanaan pembelajaran (RPP) yang sudah disiapkan. Pokok bahasan pada pembelajaran di siklus II ini adalah peristiwa kebangsaan seputar proklamasi kemerdekaan. Berikut deskripsi kegiatan pembelajaran selama penelitian.

Pertemuan I dilaksanakan pada hari Senin tanggal 15 April 2019 dengan indikator mengetahui peristiwa pembacaan teks proklamasi. Kegiatan pembelajaran diawali dengan mengucapkan salam dan mengajak semua siswa untuk berdoa menurut agama dan kepercayaan 
masing-masing. Kemudian guru mengecek kehadiran siswa dan mengajak siswa untuk menyanyikan lagu Indonesia Raya. Dilanjutkan dengan memberi apersepsi untuk mengetahui pengetahuan yang sudah dimiliki siswa. Kemudian dilanjutkan dengan memotivasi siswa dan menyampaikan tujuan pembelajaran.

Kegiatan inti diawali dengan siswa mengamati gambar yang ada dibuku siswa dan menyampaikan pendapatnya mengenai gambar tersebut. Kemudian guru mengajak siswa mencari tau keterkaitan gambar dengan peristiwa pembacaan teks proklamasi dengan cara memberikan pertanyaan-pertanyaan. Kemudian siswa membaca sebuah teks yang ada dibuku siswa lalu mengisi peta pikiran yang ada di buku siswa. Kemudian beberapa siswa diminta untuk membacakan hasil kerjanya, setelah selesai guru akan mengkonfirmasi jawaban siswa. Setelah selasai guru membagi siswa menjadi 2 kelompok besar untuk melaksanakan penerapan metode make a match. Kelompok pertama akan dibagikan kartu yang berisi soal dan kelompok kedua akan dibagikan kartu yang berisi jawaban. Setiap siswa akan mencari pasangan dari kartu yang dipegang. Setelah selesai siswa membawa pasangan kartu yang dipegang kepada guru untuk dikonfirmasi pasangan setiap kartu. Kegiatan ini diulang sebanyak 3 kali.

Pada kegiatan akhir siswa mengerjakan lembar kerja siswa yang sudah disiapkan. Setelah selesai guru mengajak siswa untuk mengoreksi jawaban bersama-sama dilanjutkan dengan guru mengajak siswa untuk membuat kesimpulan dari apa yang telah dipelajari. Kemudian guru menutup pelajaran dan mengucap salam.

Pertemuan II dilaksanakan pada hari Selasa 16 April 2019 dengan indikator mengenal proklamator kemerdekaan Indonesia. kegiatan pembelajaran diawali dengan mengucapkan salam dan mengajak semua siswa untuk berdoa menurut agama dan kepercayaan masing-masing. Kemudian guru mengecek kehadiran siswa dan mengajak siswa untuk menyanyikan lagu Indonesia Raya. Dilanjutkan dengan memberi apersepsi untuk mengetahui pengetahuan yang sudah dimiliki siswa. Kemudian dilanjutkan dengan memotivasi siswa dan menyampaikan tujuan pembelajaran.

Pada kegiatan inti siswa membaca teks yang berjudul Proklamator, kemudian guru memberikan pertanyaan mengenai bacaan tersebut. Dilanjutkan siswa menuliskan biografi sederhana mengenai bapak proklamator. Kemudian siswa membaca teks yang ada di buku siswa dan menjawab soal-soal yang ada di buku siswa. Setelah selesai guru membagi siswa menjadi 2 kelompok besar untuk melaksanakan penerapan metode make a match. Kelompok pertama akan dibagikan kartu yang berisi soal dan kelompok kedua akan dibagikan kartu yang berisi jawaban. Setiap siswa akan mencari pasangan dari kartu yang dipegang. Setelah selesai siswa membawa pasangan kartu yang dipegang kepada guru untuk dikonfirmasi pasangan setiap kartu. Kegiatan ini diulang sebanyak 3 kali.

Pada kegiatan akhir siswa mengerjakan lembar kerja siswa yang sudah disiapkan. Setelah selesai guru mengajak siswa untuk mengoreksi jawaban bersama-sama dilanjutkan dengan guru mengajak siswa untuk membuat kesimpulan dari apa yang telah dipelajari. Kemudian guru menutup pelajaran dan mengucap salam.

Pertemuan III dilaksanakan pada hari Kamis tanggal 18 April 2019 dengan indikator mengetahui kepanjangan dan peran PPKI dan BPUPKI. Kegiatan pembelajaran diawali dengan mengucapkan salam dan mengajak semua siswa untuk berdoa menurut agama dan kepercayaan masing-masing. Kemudian guru mengecek kehadiran siswa dan mengajak siswa untuk menyanyikan lagu Indonesia Raya. Dilanjutkan dengan memberi apersepsi untuk mengetahui pengetahuan yang sudah dimiliki siswa. Kemudian dilanjutkan dengan memotivasi siswa dan menyampaikan tujuan pembelajaran.

Pada kegiatan inti siswa membaca teks yang ada di buku siswa dan mengerjakan soal yang ada di buku siswa, setelah selesai guru mengkonfirmasi jawaban siswa. Kemudian guru menjelaskan materi pelajaran, setelah selesai guru melakukan tanya jawab bersama siswa. Kemudian dilanjutkan dengan mengajak siswa membuat kesimpulan. Setelah selesai guru membagikan soal evaluasi akhir siklus untuk mengetahui hasil belajar siswa setelah dilakukan tindakan dengan menerapkan metode make a match pada siklus ke II. Setelah selesai mengerjakan soal evaluasi, siswa membuat peta pikiran peristiwa kebangsaan seputar pembacaan teks proklamasi. Pada kegiatan akhir guru mengajak siswa untuk berdoa bersama, dan mengakhiri pelajaran dengan mengucap salam.

Hasil tes evaluasi pada siklus II dapat dilihat pada tabel berikut: 
Tabel 3 Rekapitulas Hasil Belajar Siklus II

\begin{tabular}{|l|c|c|}
\hline Keterangan & Jumlah Siswa & Persentase \\
\hline Tuntas & 20 & $83,3 \%$ \\
\hline Tidak Tuntas & 4 & $16,6 \%$ \\
\hline \multicolumn{2}{|c|}{ Rata-rata } & 80,83 \\
\hline
\end{tabular}

Sumber: Lampiran halaman 145

Berdasarkan tabel 4.3 dapat dijabarkan bahwa dari 24 siswa kelas $\mathrm{V}$, terdapat 20 siswa atau $83,3 \%$ sudah mencapai nilai ketuntasan dalam penelitian. Dan sebanyak 4 siswa atau $16,6 \%$ belum mencapai nilai ketuntasan dalam penelitian. Nilai rata-rata keteramilan siswa pada siklus II ini sebesar 80,2.

\section{3) Tahap Observasi}

Hasil observasi aktivitas guru dan siswa pada siklus kedua ini menunjukan bahawa adanya peningkatan. Hal ini ditandai dengan meningkatnya skor aktivitas guru dan siswa yang diperoleh.

a) Observasi Aktivitas Guru

Hasil obsevasi aktivitas guru pada sikulus II ini menunjukan bahwa aktivitas guru dalam membuka pelajaran sudah baik. Garu dapat memusatkan perhatian siswa dengan suara yang lantang. Pada pertemuan pertama guru memberikan motivasi dengan cukup baik, namun bahasa yang digunakan guru berbelit-belit sehingga susah untuk dipahami siswa. Selain itu materi yang disampaikan guru kurang sesuai dengan tujuan pembelajaran. pada pertemuan pertama guru memperoleh nilai 73,33.

Pada pertemuan kedua guru memberikan apersepsi dan motivasi dengan bahasa yang sulit dipahami siswa, sehingga siswa kurang merespon kegiatan tersebut. Pada kegiatan inti dan penutup guru melaksanakan aktivitasnya dengan baik, hanya saja suara guru terkadang tidak terdengar dengan jelas. Pada ssat memberi tindak lanjut guru memberikan arahan dengan suara yang kurang jelas, sehingga hanya sebagian siswa yang merespon kegiatan tersebut. Pada pertemuan ini guru memperoleh nilai 74,77.

Hasil observasi pada pertemuan ketiga menunjukan bahwa guru membuka pelajaran dengan sangat baik, hampir semua siswa merespon kegiatan ini, guru juga mampu memusatkan perhatian siswa. Pada kegiatan inti guru dapat mengkaitkan materi dengan kehidupan siswa dengan baik. Guru juga memberikan penjelasan materi pelajaran dengan suara yang jelas dan lantang, sehingga siswa lebih antusias dalam mengikuti kegiatan pembelajaran. Pada
Pertemuan ini aktivitas guru mendapat nilai sebesar 78,88.

b) Observasi Aktivitas Siswa

Hasil observasi aktivitas siswa pada pertemuan pertama menunjukan bahwa sebagian besar siswa menunjukkan minat belajarnya dengan antusias siswa melaksanakan intruksi dari guru dan merespon setiap stimulus yang diberikan oleh guru. Namun pada pertemuan ini masih ada aspek yang perlu ditingkatkan, yaitu perhatian siswa. Pada pertemuan ini masih ada siswa yang tidak memperhatikan penjelasan guru dan asik mengobrol. Aktivitas siswa pada pertemuan ini memperoleh nilai 73,33.

Observasi pada pertemuan kedua menunjukan bahwa jumlah siswa yang memperhatikan penjelasn guru meningkat, namun pada aspek lain masih mendapatkan skor yang sama dengan pertemuan sebelumnya, sehingga pada pertemuan kedua hasil observasi aktivitas siswa memperoleh nilai 80. Pada pertemuan ketiga sekor yang diperoleh untuk aspek perhatian siswa kembali meningkat selain itu keaktifan siswa pada pertemuan ini juga meningkat, sehingga nilai yang diperoleh pada pertemuan ketiga adalah 86,66 .

\section{4) Tahap Refleksi}

Setelah melaksanakan siklus II peneliti melakukan Refleksi terhadap kegiatan pembelajaran pada siklus II. Refleksi ini dilakukan sebagai bahan pertimbangan apakah akan melanjutkan penelitian pada siklus III atau tidak. Berdasarkan data-data yang diperoleh pada siklus II, peneliti dapat penyimpulkan bahwa pada tes akhir siklus II mengalami peningkatan dari tes akhir siklus I. Dan hasil yang diperoleh dari tes akhir siklus II ini sudah mencapai indikator keberhasilan dalam penelitian ini, yaitu $80 \%$ siswa mencapai nilai $\geq 80$ dengan predikat baik. Dengan persentase siswa yang mendapat nilai $\geq 80$ adalah $83,3 \%$ atau sekitar 20 siswa.

\section{Discussion}

Berdasarkan data yang diperoleh dalam melaksanakan penelitian menunjukkan bahwa penggunaan metode make a match dapat meningkatkan hasil belajar siswa kelas V SDN 020 Samarinda Utara. Hal ini menunjukkan bahwa penggunaan metode dalam pembelajaran dapat menarik perhatian siswa sehingga dapat meningkatkan hasil belajar siswa. Hal ini sejalan dengan apa yang dikemukakan oleh 
(Mariyaningsih \& Hidayati, 2018) penggunaan metode pembelajaran bertujuan untuk mengoptimalkan kegiatan pembelajaran untuk mencapai tujuan pembelajaran.

Peningkatan hasil belajar siswa dapat dilihat dari rata-rata kelas dan persentase ketuntasan yang diperoleh selama penelitian. Peningkatan tersebut dapat dilihat pada grafik berikut:

\section{Grafik 1 Rekapitulasi Hasil Belajar}

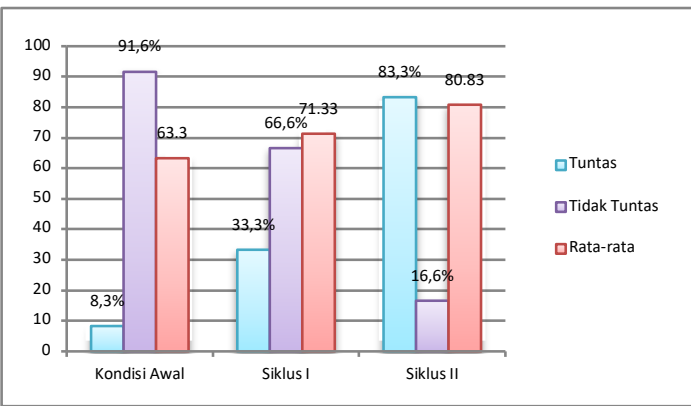

Berdasarkan Grafik 1 dapat dijabarkan bahawa hasil belajar siswa yang diperoleh pada saat sebelum dilakukan tindakan yaitu 63,3 dengan persentase ketuntasan $8,3 \%$, setelah dilakukan tindakan pada siklus I memperoleh nilai rata-rata 71,33 dengan persentase ketuntasan $33,3 \%$ kemudian pada siklus II dengan nilai ratarata 80,83 dengan persentase ketuntasann $83,3 \%$. Sedangkan untuk siswa yang belum mencapai nilai ketuntasan diserahkan pada guru kelas untuk diberikan remedial. Hasil penelitian juga menunjukkan bahwa penerapan metode make a match juga dapat meningkatkan keterampilan siswa. hal ini dibuktikan dengan nilai rata-rata keterampilan siswa pada siklus I yaitu 68,8 , meningkat pada siklus II dengan nilai rata-rata 80,2 .

Hasil observasi yang dilakukan selama penelitian berlangsung menunjukkan bahwa dengan menerapkan metode make a match dalam pembelajaran dapat meningkatkan aktivitas guru dan siswa. Hal ini dibuktikan dengan hasil observasi aktivitas guru pada siklus I pertemuan pertama mendapat nilai 48,8 , pada pertemuan kedua meperoleh nilai 56,6 , dan pada pertemuan ketiga memperoleh nilai 58,8. Aktivitas guru meningkat pada siklus II, dibuktikan dengan observasi aktivitas guru pada pertemuan pertama mendapatkan nilai 73,3 , pada pertemuan kedua mendapat nilai 74,7 dan meningkat kembali pada pertemuan ketiga dengan nilai 78,8 .
Observasi aktivitas pada siklus I menunjukkan bahawa keaktivan siswa dalam mengikuti kegiatan pembelajaran belum maksimal, hanya sebagian siswa yang aktif dalam kegiatan pembelajaran. Hal ini dikarenakan siswa masih kurang berani dalam menyampaikan pendapatnya. Pada siklus II guru merencanakan untuk meningkatkan keaktifan siswa dengan memberikan poin pada siswa yang berani menjawab pertanyaan dan siswa yang berani memberikan tanggapan. Sehingga aktivitas siswa pada siklus II meningkat. Adapun peningkatan aktivitas siswa dapat dilihat pada grafik berikut:

\section{Grafik 2 Rekapitulasi Observasi siswa}

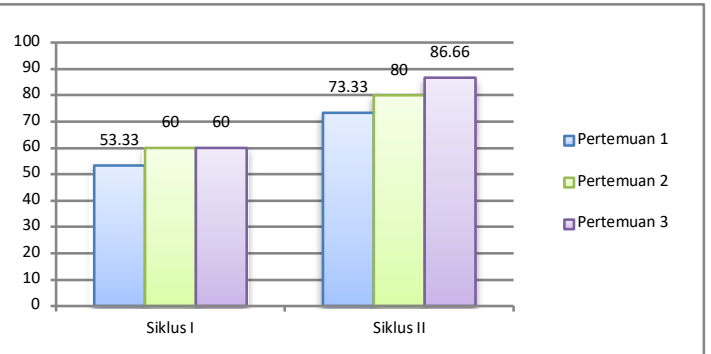

Berdasarkan grafik 2 dapat dijabarkan bahwa skor aktivitas siswa yang diperoleh pada siklus I pertemuan pertama yaitu 53.33, pada pertemuan kedua memperoleh skor 60 , dan pada pertemuan ketiga kembali memperoleh skor 60 . Sedangkan pada siklus II sekor aktivitas siswa terus meningkat disetiap pertemuan. Skor yang diperoleh pada pertemuan pertama yaitu 73.33, dan meningkat pada pertemuan kedua dengan skor 80, dan kembali meningkat pada pertemuan ketiga dengan skor 86.66.

Berdasarkan analisis data yang diperoleh selama penelitian menunjukkan bahwa hasil belajar siswa meningkat pada tema peristiwa dalam kehidupan pada muatan pelajaran IPS dengan materi peristiwa kebangsaan pada masa penjajahan dan proklamasi kemerdekaan. Hal ini sesuai dengan yang diungkapkan (Mariyaningsih \& Hidayati, 2018) yaitu, penggunaan metode make a match dapat meningkatkan aktivitas belajar, menyenangkan karena ada unsur game, dan meningkatkan kemampuan berkomunikasi siswa, dan ketiga hal tersebut mempengaruhi hasil belajar baik dalam ranah Kognitif maupun pada ranah psikomotorik.

Peningkatan hasil belajar siswa pada penelitian ini didukung beberapa penelitian yang sejalan. Penelitian pertama oleh (Indrastuti et al., 
2017) tentang peningkatan hasil belajar siswa melalui metode make a match pada siswa kelas IV SDN Beluk Kelaten dengan nilai rata-rata kelas sebesar 74,00 pada siklus I, dan meningkat pada siklus II menjadi 86,00. Penelitian lain dari (Yunita et al., 2018) tentang keefektifan model pembelajaran make a match terhadap prestasi belajar peserta didik pada siswa kelas XI IPA SMAN I Dukuhwaru, yakni terdapat perbedaan prestasi belajar peserta didik yang diajar menggunakan model pembelajaran make a match dengan menggunakan model pembelajaran konvensional. Selain itu diketahui juga bahwa model pembelajaran make a match lebih baik dari model pembelajaran konvensional dalam meningkatkan prestasi belajar peserta didik.

\section{Conclussion}

Berdasarkan hasil penelitian dan pembahasan dapat disimpulkan bahwa penggunaan metode make a match dapat meningkatkan hasil belajar siswa kelas V SD Negri 020 Samarinda Utara tahun pelajaran 2018/2019 pada tema peristiwa dalam kehidupan pada muatan pelajaran IPS dengan materi peristiwa kebangsaan pada masa penjajahan dan proklamasi kemerdekaan.

Peningkatan tersebut dapat dilihat dari peningkatan jumlah siswa yang mendapatkan nilai ketuntasan yang pada kondisi awal berjumlah $8,3 \%$ dengan nilai rata-rata 63,3 , meningkat pada siklus I berjumlah $33,3 \%$ dengan nilai rata-rata 71,33, dan meningkat kembali pada siklus II dengan jumlah $83,3 \%$ dengan nilai rata-rata 80,83 . Hasil belajar siswa pada siklus II telah mencapai indikator keberhasilan dalam penelitian ini, yaitu $80 \%$ siswa mencapai nilai $\geq 80$ dengan predikat baik. Selain hasil belajar, penerapan Metode make a match juga dapat meningkatkan keterampilan siswa dalam membuat peta pikiran. Hal ini dapat dilihat dari nilai rata-rata yang diperole pada siklus I sebesar 68,8 , meningkat menjadi 80,2 pada siklus II.

\section{References}

Arikunto, S., Suhardjono, \& Supardi. (2014). Penelitian Tindakan Kelas. ALFABETA.

Arikunto, S., Suhardjono, \& Supardi. (2017). Penelitian Tindakan Kelas (Suryani (ed.); 2nd ed.). Bumi Aksara.
Darmadi, H. (2017). Pengembangan Model \& Metode Pembelajaran dalam Dinamika Belajar Siswa (1st ed.). Deepublish.

Daryanto. (2018). Penelitian Tindakan Kelas Dan Penelitian Tindakan Sekolah (1st ed.). GAVA MEDIA.

Djamarah, S. B. (2014). Guru Dan Anak Didik Dalam Interaksi Edukatif (1st ed.). RINEKA CIPTA.

Indrastuti, W., Utaya, S., \& Irawan, E. B. (2017).

PENINGKATAN AKTIVITAS DAN HASIL BELAJAR SISWA MELALUI PEMBELAJARAN KOOPERATIF TIPE MAKE A MATCH. Jurnal Pendidikan: Teori, Penelitian, Dan Pengembangan, 2(8), 1037-1042.

Kunandar. (2016). Langkah Mudah Penelitian Tindakan Kelas Sebagai Pengembangan Profesi Guru (10th ed.). RAJAGRAFINDO PERSADA.

Kusnadi. (2018). Metode Pembelajaran Kolaboratif (T. Muhammad (ed.); 1st ed.). Edu Publisher.

Mariyaningsih, N., \& Hidayati, M. (2018). Bukan Kelas Biasa (A. Kusuma Putra (ed.); 1st ed.). CV Kekata Group.

Setiawan, A. (2017). Belajar Dan Pembelajaran (Fungky (ed.); 1st ed.). Uwais Inspirasi Indonesia.

Setiawan, R. (2017). Penelitian Tindakan Kelas (Action Research). Nuha Medika.

Susanto, A. (2016). Teori Belajar \& Pembelajaran di Sekolah Dasar (4th ed.). Prenadamedia.

Yunita, T., Susongko, P., \& Utami, W. B. (2018). KEEFEKTIFAN MODEL PEMBELAJARAN MAKE A MATCH TERHADAP PRESTASI BELAJAR PESERTA DIDIK. Jurnal Pendidikan MIPA Pancasakti, 2(2).

Zarkasyi, W., Lestari, K. E., \& Yudhanegara, M. R. (2017). Penelitian Pendidikan Matematika (Anna (ed.); 2nd ed.). Refika Aditama. 